\title{
THE ROLE OF INFORMAL CAREGIVERS FROM THE COMMUNITY NURSE'S PERSPECTIVE: QUALITATIVE STUDY
}

\author{
Aurelija Blaževičienė $\dot{2}^{2}$, Alina Vaškelytė ${ }^{1,2}$, Aušra Kunčiene் ${ }^{2}$ \\ ${ }^{1}$ Kaunas University of Applied Sciences Fakulty of Medicine Nursing Department, \\ ${ }^{2}$ Lithuanian University of Health Sciences Nursing and Care Department
}

Keywords: informal caregivers, community nurses, home care, qualitative study.

\begin{abstract}
Summary
Patients with chronic health care conditions who require long-tern care are nursed at home, therefore, there is a shift in responsibility for their care from paid formal caregivers to unpaid family members. Aim of this study was to assess the role of informal caregiver's in-home care from the community nurse's perspective.

Thirty-one nurses, providing home care services to patients with special needs requiring constant care, participated in five semi-structured focus-group discussions. The data analysis was based on descriptive phenomenology.

Three distinct phases in the development of informal caregiver-nurse relationship was uncovered: (1) the first phase is associated with the organization of home care in the family context, (2) the management of possibilities and challenges faced by informal caregivers in-home care phase; (3) the impact of home care on informal caregivers' quality of life and health phase.

This study result shows that in organizing home care for the elderly are lack of cross-sectoral cooperation and teamwork between informal caregivers and community nurses. Therefore, informal caregivers must accept a new role in life as a provider of care, advocating, and supporter roles. Furthermore, as a result of daily fatigue, the informal caregivers' quality of life is deteriorating and their social exclusion is increasing.
\end{abstract}

\section{Introduction}

Demographic change caused by an aging population and increasing life expectancy are factors leading to increasing demand for health care and social services specifically directed at health care issues of older and disabled people [1]. These factors have created a financial crisis in health care sector and require us to explore other solutions such as home care. Patients with chronic health care conditions who require long-tern care are nursed at home, therefore, there is a shift in responsibility for their care from paid formal caregivers to unpaid family members. Furthermore, the growing number of older people in need of long-term care has increased the demand for and fundamentally changed the nature of home care $[2,3]$. Finally, as technology advances, treatment services that were previously restricted to hospitals have been authorised in home-care settings $[4,5]$.

According to research data, it is proposed that family members and informal caregivers provide care for $85 \%$ of older patients while formal caregivers such as community nurses and family physicians provide care for the remaining $15 \%$ of older patients $[6,7]$. Based on scientific research, it may be presumed that patients in need of care would like to be nursed in their own homes and home remains the preferred place of care. However, provision of care services at home involves a place where the patient's and his/her family values, attitudes, habits, power and control balance prevail. Overcoming this complex scenario requires a great deal of common sense experience and scientific evidence [8,9].

The underdevelopment of home care services increasingly causes more physical, psychological, social and ethical problems for both the health of care recipients and the informal caregivers' quality of life. Consequently, care recipients are more frequently hospitalised, informal caregivers wish to place care recipients in long-term care institutions $[10,11]$.

During this decade, increasing attention has been paid to cooperation with nurses being encouraged to develop "partnership" with informal caregivers in hospitals, nursing homes, and the community [12].

Collaboration between nursing staff and family members in the home care of older people has recently received increasing research attention, but even so this remains a comparatively under-researched area [13]. However, most studies focused on cooperation analysis from the informal 
caregivers' point of view.

Following the EU Member States practice, Lithuania aims to ensure that elderly continue to live in their own homes for as long as it is possible. Therefore, the provision of home care services is defined as one of the priorities of the National Health Care Strategy [14]. In Lithuania, outpatient care services provided at home are funded by the Compulsory Health Insurance Fund since 2008. Although there is an annual increase in this type of funding (EUR 1.7 million in 2009, EUR 5.9 million in 2017, EUR 6.9 million in 2018), the home care expenditure is twice as low compared to most EU Member States and constitutes only $5.8 \%$ of total health care costs [15]. Until 2021 one service recipient can receive outpatient home care services funded by the CHIP only 24 times per calendar year, from 2021years - outpatient home care services increased to 104 visits per calendar year [16].

Problems related to meeting the needs of patients in home care, ensuring self-care, changes in the informal caregivers' quality of life, alongside the challenges of caregiving are just beginning to be addressed in Lithuania [17]. Attitudes of nurses' towards informal caregivers are the new area of research in the practice of Lithuanian nursing professionals.

This study aims to assess the role of informal caregivers' in-home care from the community nurse's perspective.

\section{Methods}

The team of researchers chose a qualitative descriptive phenomenological research approach to gain information on the development of the informal caregiver-nurse relationship, which was investigated as a phenomenon. Data were gathered by holding focus-group discussions, which facilitated the researchers to obtain a more in-depth understanding of the experiences and personal insights of the participants.

The study was performed in Primary Care Centres and Family Physician Clinics in Lithuania. The participants were community nurses providing home care services to patients with special needs requiring constant care. In total, $31 \mathrm{com}-$ munity nurses participated in the study. The average age of respondents was 57.61 years with the average length of service being 33.19 years. Participation was on a voluntary basis with no reward for participation offered or provided. The participants were informed of the aim and objectivesof the study, as well as their rights and entitlement to terminate their participation at any time. Participants then signed an informed consent form and completed an anonymous questionnaire that obtained details such as their age, gender, relationship with the care receiver, and the length of time they had been providing care. For confidentiality reasons, participants were asked not to mention any given or family names during the discussions.
Five semi-structured focus-group discussions were held. Each focus group comprised 5-9 participants, each discussion was audio-recorded. The structure of the discussion was monitored by the researcher, who asked three pre-prepared open questions, but the participants could also discuss other aspects and were encouraged to share any experiences they thought were relevant.

The three prepared questions were: 1) What are the attitudes of nurses towards the roles of informal caregivers in ensuring home care for special needs patients? 2) What are the possibilities for informal caregivers to provide home care for special needs patients from the community nurses' point of view? 3) What are the obstacles encountered by informal caregivers in the process of home care for special needs patients from the community nurses' point of view? At the end of each discussion, the researcher asked an additional question: "Are there any other aspects of your experiences that have not been discussed that you think are important to mention?" The focus-group discussions lasted 45-70 minutes, depending on the size of the group and the depth of discussion that occurred in response to the additional information provided by participants. Saturation of the theme was reached after the fourth focus-group discussion, as the fifth focus-group discussion provided no new content; consequently, the data collection was stopped after the latter discussion.

After the five focus-group discussions had been completed, the audio recordings were transcribed verbatim. Two independent researchers systematically reviewed the entire dataset and coded the data by selecting the closest coding terms for the words used by the participants. Later, each researcher's coded transcripts were compared with the others, and this showed that the majority of the codes were similar. Any coding differences that were found were resolved through securing common consent among the researchers. Thematic categories were composed by grouping similar codes, and these were then formulated into main themes. The data analysis was based on the descriptive phenomenology. Study participants gave meaning to their own experience while researchers explained the phenomenon [18]. In discovering the essential structure of the phenomenon, the researcher instead of individuals focused on the phenomenon itself (development of informal caregiver- community nurse relationship) and how this phenomenon was experienced by various individuals (informal caregivers and nurses based on the community nurses' experience.

\section{Results}

This study revealed experiences of nurses, from one region of Lithuania, providing care services at home, on col- 
laboration with informal caregivers responsible for the home care of family members.

Three distinct phases in the development of informal caregiver-nurse relationship were uncovered: (1) the first phase is associated with the organisation of home care in the family context, including creation of new roles for family members, establishing collaboration with nurses and close interdependence with a person in care; (2) the management of possibilities and challenges faced by informal caregivers in home care phase, during which informal caregivers get involved and prepared for home care in order to ensure the continuity of twenty-four hour care services, the need for formal and informal assistance and respite services is evaluated; (3) the impact of home care on informal caregivers ${ }^{6}$ quality of life and health phase is associated with social and economic burder of care, physical and emotional health problems, spiritual and ethical issues of home care (Fig. 1).

Organisation of home care in the family context. Nursing at home involves continuing relationships of family members with informal caregivers. According to the participants, care recipients continue to live together with or separately from their caregivers - a spouse, children, parents. Only a very small fraction of informal caregivers does not experience any changes in theirs lives. Most caregivers have to coordinate home care needs with each other taking into consideration the situation and capabilities of every family member. Participants emphasized the importance of home environment and presence of informal caregivers in the organisation of home care (Did all participatns emphasize this?). Nurses highlighted that if it was possible to ensure efficient and quality care at home, it was always more beneficial for the care recipient to be with family members. Informal

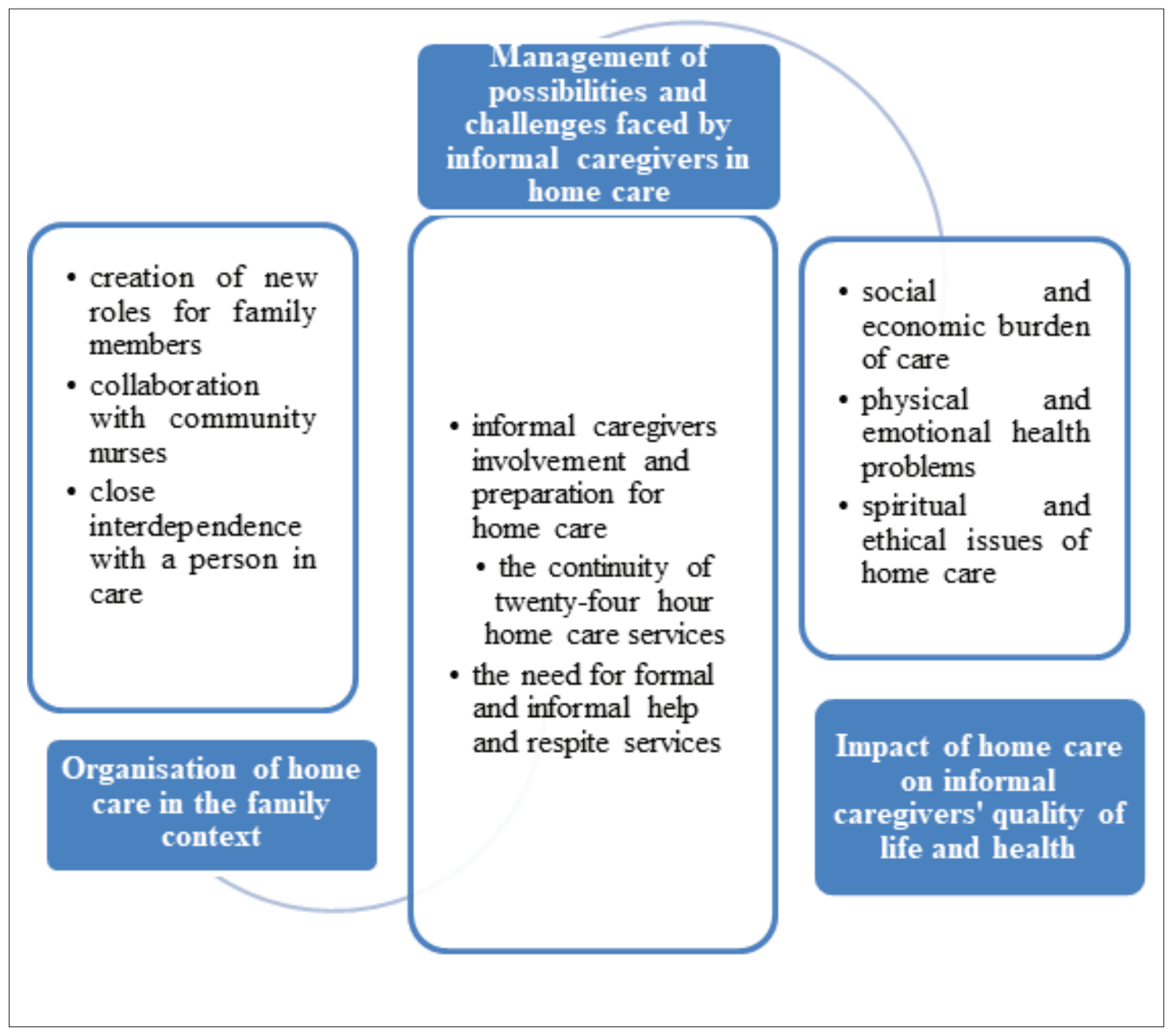

Figure 1. Development of informal caregiver-community nurse relationships 
caregivers address most of the home care needs. Nurses perceive their work only as assistants to informal caregivers:

Of course, the best care is at home, not only your own environment, home but there are assistants like children, grandchildren (Informant 8). <..> it is safer with your own, they know better what is needed (Informant 19).

$<\ldots>$ the role of relatives is crucial. We just, well, we visit once a month (Informant 10).

The family structure is changing as children leave home early, husbands emigrate abroad, women longer remain active in social life and pursue careers. Although traditional understanding of family roles is changing, the nurses' comments preserved the stereotypical approach:

It has long been accepted to take care of the sick at home, as long as relatives can take care of it themselves $<\ldots>$ (Informant 11).

Although nurses seek to involve the whole family in home care, most frequently the role of informal caregiver is taken up by a family member who is single or lives with the person in need of care. Retired, older, even disabled women engage in home care with great dedication, even exaggerated concern. Unemployed informal caregivers first of all seek to obtain the legal status of an informal caregiver, which provides for social guarantees.

According to the pariticipants informal caregivers become the care recipient's needs assesors, their teachers, take up the role of the care recipient's representative and advocate, when they attend medical institutions, they also provide information to nurses, family physicians about health problems, medications and their effect, the need for care aids and social services:

When I come and see them for the first time, I can't objectively assess the nursing needs $<\ldots>$. Relatives always know best what is better for the person in their care, what he likes, what he dislikes (Informant 6).

The participants maintain that no matter how much state funded home care services are provided, they find it important to provide support and assistance to informal caregivers in their efforts. The majority (is that true?) of the pariticants acknowledged that their partnership with informal caregivers is linked with responsibility, nursing procedures, roles, emotions in the home care process.

We have to take blood, urine tests, record a cardiogram, measure intraocular pressure, oxygen, check the pulse, manage bedsores, administer drips and intravenous medication. The rest from a bedpan to daily food, from handing a pill to giving an enema is done by relatives (Informant 11).

The difficulties experienced by the participants in ensuring home care and cooperating with informal caregivers was revealed. Although the nurses plan regular visits, they usually visit only once a month or upon a request from relatives. As their health deteriorates, complex health care issues are addressed, however, the number of professional care services that can be provided does not increase.

$<\ldots>$ you can expect a nurse to visit once a month, if something is unclear, they may be visited by a nurse on appointment, to talk, to discuss medication, care (Informant 4).

Some nurses did not identify any problems in the home care process, while others indicated problems related to the organisation of home care such as limited funding for services, lack of coordination and the ever-changing legal regulation of home care services:

$<\ldots>$ there is no control, some sort of coordination of their health status. How often do we visit the patient, maybe once a month, and if the condition is the same and relatives do not ask for help, then even less often. Then it is quite unexpected when the relatives show up to report their death and ask for a death certificate (Informant 5).

The needs of care recipients and informal caregivers are significantly different in the home care setting, however, the dependency of patients on their informal caregivers is evident. Once patients lose their autonomy and independence, the presence of informal caregivers, safety and stability ensured by them, emotional support provided for the patient become very important.

[You] can't go anywhere, [you] have to inject insulin, check sugar levels, make meals (Informant 9).

Informal caregivers need more patience, and efforts to maintain respectful communication and relations. There are no strict boundaries and rules between patients and informal caregivers in the home care environment. In contrast, distance maintained by nurses makes nursing the focus of communication:

Some patients expect communication, attention. Relatives say they miss it, wait for it when a nurse comes and measures the blood pressure. Even though the blood pressure is checked by the daughter every day. They need it, they want to talk, with relatives or caregivers they have conflicts, get tired of each other (Informant 6).

Nurses indicated neglect on behalf of some children towards their parents' home care. The absence of meaningful relationship between parents and children lasting since their childhood reflect on their relationship at old age. If there is no interdependence and closeness between children and parents, it cannot be brought back by illness.

Possibilities and challenges faced by informal caregivers in home care

Evidence from the literature highlights the significant negative impact of care giving on the physical, mental and financial aspects of caregivers' lives. It also reinforces the 
importance of reducing the barriers to meeting the unmet needs of caregivers and that research priorities in intervention development need to focus on reducing the negative aspects of care giving (Girgis, 2006).

Relatives/caregivers try to accept home care asa task, become active, independent, responsible informal caregivers:

There is a bedridden patient, medicines and diapers are compensated for, they themselves are economically sustainable. [They] manage everything.

At the beginning of care nurses determine the need for assistance in home care by considering the patient's physical and social autonomy, the home environment, as well as informal caregivers' capabilities to provide care. However, this type of assessment does not provide for a comprehensive review of the relatives' abilities to provide full-scale home care. Therefore, nurses generally rely on a broader assessment of informal caregivers' preparation, understanding of the illness and the care required:

Already during the first visit at home, while defining the needs, we discuss with relatives how home care will be provided. Will they be able to take care all day or will they ask the social services centre for some of the services? (Informant 12).

According to particiants not all informal caregivers are motivated to get involved in home care. It is possible to find irresponsible relatives' attitudes towards nursing with some relatives demonstrating limited/low health literacy. Information provided at the beginning of home care, alongside knowledge obtained at the hospital prove to be insufficient for informal caregivers once they are back at home. Although it is not formally defined, the learning process continues to be a part of the informal caregiver - nurse relationship during each home visit. Nurses believe that accurate information about the illness, changes in health condition, appropriate communication, behaviour towards the patient and safe and proper care are very important to informal caregivers. In assesing the patient's needs, self-care and their health condition, nurses rely on information provided by informal caregivers.

We come to assess the general condition: if there are bedsores, if bedsores are gone, if there is a headache or not, if [the patient] sleeps at night or not, if the medication prescribed by a doctor is taken or not, if the blood pressure is measured or there is no control. We come to a person and try to determine what the most important needs of the patient are at the moment (Informant 10).

According to nurses, home care takes most of informal caregivers' time, therefore, it is extremely important to plan and coordinate, to distribute tasks among family members. Family members provide home care and ensure the patient's safety around-the-clock. It is only natural that if one relative takes the bigger nursing load, he or she often needs help:

If you think about it, the working day lasts for eight hours, while the patient has to be taken care of for twentyfour hours, then there should be at least three relatives by his side (Informant 12).

At present, the home care tasks fall on one or on two informal caregivers. Nurses maintain that througout the nursing period informal caregivers try to be self-sufficient and not always willing to accept help. Visiting once a month nurses find it difficult to manage, control the nursing process and medication intake. Nurses observed that sometimes the complexity of nursing facilities and actions made them to question the ability of informal caregivers to provide accurate and required care:

If there are bedsores, open wounds, it is not clear how they treat them, whether they avoid causing additional pain. We consult the family physician; the company's representative comes by. We use AQAUCEL dressing. It seems you explain how to do it and then again find some ointment, herbs on the wound (Informant 11).

There was a difference in opinion among nurses about the housing conditions necessary for home care. Some participant ts indicated poor housing conditions that worsened the situation of relatives in home care. Other nurses believed that there was no need for special adaptation of accomodation.

Study participants indicated the need for a special institution that would focus solely on home care services, evaluate and take care of living conditions, provide informal caregivers with information on benefits, administer submission of various documents. Nurses observed that informal caregivers lacked information on organisations providing medical, psychological, social support:

Families often lack information on how to take proper care of the patient, where to seek help. A so-called service map containing all information on medical, nursing, social services is very much needed (Informant 9).

Nurses' statements suggest that they perceive care allowance as payment to informal caregivers for nursing, but not as means for improvement of the patient's conditions at home or purchasing of care aids. Study participants expressed the need to control the nursing costs by allocating separate sums for the patient's care and for the needs of informal caregivers:

If there was centralised distribution of money, for instance: some for the patient, some for training, some for visits, this would be more beneficial for the patient. There would be some control over the nursing process (Informant 10).

Nurses acknowledge that informal caregivers spend a significant amount of care allowance on care/medical aids. However, informants believe that the number of reimbursed 
diapers, blankets, bedsore remedies should be increased:

This kind of home care, when diapers are unchanged, they are being saved, as the compensation is only for 30 pieces per month. Although if you look at it, there is a significant amount of money, it includes pension and care allowance. And it is definitely not used for nursing (Informant 8).

Informants believe that state support is insuficient, it is necessary to increase the number of visits by both nurses and social workers:

What we have is the centre of social services that provides care for several hours per day, and we visit once a month, what family members should do at night, they can't sleep either (Informant 13).

Nurses believe that one person cannot ensure the nursing process. In assessing the possibilities for home care, it has to be known who would provide care, to train and include all family members, relatives, hired assistants:

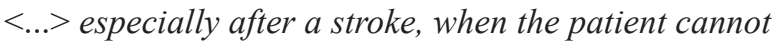
move, has to lie down. And the possibility to provide aroundthe-clock care is feasible only when there are more people in the family, children, grandchildren, relatives. And for those with only one spouse or child it is nearly impossible (Informant 28).

Impact of home care on informal caregivers' quality of life and health. Informants maintain that informal caregivers often fail to reconcile home care and professional life, their quality of work deteriorates, therefore, their ability to keep the place of employment and provide home care is entirely dependent on the employer's awareness. Informal caregivers who fail to reconcile work with home care lose their jobs, which means that the state support is then required for at least two people.

If you think about it, this nursing of a relative, it is like a sacrifice of your life, you have to give up even that public job (Informant 1).

As a result of everyday fatigue, the informal caregivers' quality of life is deteriorating, they lose the ability to realise their potential, the quality of communications as well as close friendships are negatively affected. Informal caregivers tend to spend increasingly less time on communication with relatives. The form of communication is also changing, it is more constructive, with the communication focus shifting to the patient and about the patient.

I can say that my relatives are isolated, they don't communicate with anyone, they don't go out anymore, all their talk is about the granny, there are no friends left (Informant 25).

The study has revealed that there were changes in hobbies of informal caregivers, they had to give up some hobbies, there was no time left for cultural activities. The patient's illness promotes an interest in alternative medicine, psychology, nursing:

I think they attend very few events as they do not talk about it, but they are interested in all types of medicine, read journals on psychology both for their own sake and also to find out more about the illness (Informant 29).

Informants indicate that after half a year of providing regular care informal caregivers' health is affected, during each home visit they keep complaining about their own physical disorders:

Providing home care for the patient, especialy the one who is bedridden, a person could last without any harm to his or her health, well, maybe half a year, as it is very intense physical effort (Informant 18).

And how can you help them, they cannot be hospitalised. They have to be healthy, so we visit the patient and treat relatives at the same time (Informant 22).

Nurses indicated that first of all informal caregivers complain about fatigue, sleep deprivation. Older informal caregivers similarty to patients have to take prescribed medicines, manage their own illnesses. Nurses pointed out that turning or repositioning a patient in bed most frequently caused back and arms pain in caregivers. In the long run, such health problems tend to accumulate and informal caregivers themselves need nurses' help. Informants emphasised that in the home care setting the help of health care professionals was necessary for the patient as well as for informal caregivers.

All informants acknowledged the impact of nursing on the emotional wellbeing of informal caregivers. A sudden illness of a family member and long-term care, lifestyle changes and first difficult moments of nursing most frequently trigger shock and stress for informal caregivers. Stress is mutual for informal caregivers and patients. Family members live in a constant state of tension fearing for deterioration of the patients' condition.

During the process of home care there are cases when the patients' family members are angry with one another and conflict can emerge. Men are less tolerant of constant care and they may begin consuming alcohol (Akgun-Citak et al., 2020). Nurses notice that informal caregivers can become angry, irritated, highly sensitive and emotionally unstable individuals. Informal caregivers perceive home care as duty, daily work, sacrifice, dependence, thereby forgetting the duty to live their own life. In this case, the help provided by nurses is insufficient and professional assistance of other healthcare professionals, such as, psychologist, psychiatrist is necessary, which according to nurses, is lacking.

Inpatient care services turn into months of respite for relatives/caregivers, when their own health issues are addressed: 
In case of severe exhaustion/fatigue, a person (relative) may visit a family physician, then the patient is hospitalised in the nursing department (Informant 17).

Informal caregivers' and patients' feelings related to dying and attitudes towards death, their relationship to church and the clergy indicating the influence of religion are not discussed during nurses' visits. Nurses' observations emphasise the necessity of meeting patients spiritual and religious needs:

$<\ldots>$ [her] clasped bony fingers holding rosary, I don't ask anything about it $<_{\text {... }}>$ (Informant 22).

By focusing only on physiological patients' needs in home care, it can be easily forgotten that a patient even in a very difficult condition remains spiritually rich and emotionally stable. Nurses believe that exhausted informal caregivers are more in need of learning to appreciate life. According to the pariticpants, family members have no time to discuss illness, suffering and death. In their opinion, clerical visits should be included in addition to home care services.

In the beginning of home care, nurses and social workers bring along tension and vulnerability into the family, therefore, addressing home nursing situations is very important in developing ethical nursing practices:

Some [people] do not want for strangers from the social services centre to be at home, they feel discomfort of someone walking around the house. And they can feed [the patient] themselves, to take care, only they need to be trained. Well, if they work, then the situation is different (Informant 16).

It is possible to identify an ethical dilemma/conflict in focusing on precise nursing activity documentation procedures instead of listening carefully and attentive communication, which are not legally defined. Home care should be characterised by individuality, instead of strict procedural framework.

Nurses also point out situations when informal caregivers find it emotionally difficult to accept death. As patients' condition deteriorates, informal caregivers experience panic and fear. In the event of a terminal condition they ask for resuscitation, to do everything to prevent patient's death and may evendemand hospitalisation.

Nurses believe that the burial of the deceased is morally challenging for informal caregivers. Therefore, continuous and final nursing goals, according to informants, should focus on the provision of assistance to informal caregivers during and after the period of bereavement.

\section{Disscussion}

Outpatient home care services are directed at the continuity of services provided at Primary Care Centres. Collaboration between formal and informal home care providers remains problematic in the context of respect, trust and coordination [19]. Our results showed that in the context of organising home care, the collaboration of health care staff is problematic, precisely because of the lack of coordination, limited funding and the ever-changing legal regulation of home care services.

A study carried out in Spain concluded that $5.9 \%$ of women and $7.9 \%$ of men did not receive any informal care at home. According to a study conducted in Canada, approximately $2 \%$ of older people did not receive the necessary care from family members [20]. Our study results demonstrate that in case of lonely patients the provision of home care by informal caregivers is very problematic and they can rely only on nursing and care provided by nurses and social workers.

According to a Norwegian researches home care services are not limited by a specific time period but are based on individual needs of care recipients and informal caregivers' possibilities to provide care [21]. In contrast, nurses in our study regretted the lack of differentiation between conditions of care recipients. The longer the period of home care, the more difficult/complex patients' health problems need to be addressed, the demand for care services is increasing, however, the number of professional care services to be provided remains the same. The several studies maintained that short-term hospital stays and deterioration of health while nursing at home tended to increase the probability of repeated hospitalisation $[21,22]$. There is no rush in solving patients' problems at home and, if their condition deteriorates, informal caregivers are willing to choose the possibility of repeated hospitalisation.

The findings of our study revealed that the assessment of informal caregivers' roles in provision of home care shows that informal caregivers accept some roles of patients as they become nursing need assessors, teachers, representatives and advocates, coordinators, and managers seeking to ensure appropriate home care. Poland et al. (2014) concluded that informal caregivers acquired the role of nurses by performing medical procedures, assessing changes as the patient's condition progressed [23].

The findings of our study revealed that older women were more considerate, while younger informal caregivers were more engaged in the home care process, more interested and willing to learn, looking for information on a specific nursing issue in the internet or in the press or television. The younger informal caregivers expressed much more interest in influencing the nursing process compared to older caregivers [24]. The younger generation of caregivers lives separately from care recipients, while the older generation of caregivers, like spouses, continue to live in the same household. In our 
study nurses noted the problem of family-wide involvement since nursing was provided by those living with the person in need of care - a wife, a mother, or children. Children coordinate nursing efforts among themselves considering each other's situation as help provided by relatives is very limited or non-existent.

Conflict between having a well-paid job and the necessity of nursing as an additional burden on family members in the provision of home care [25]. In our study the participants also highlighted cases when the patients' family members were angry at each other, engaged in conflicts, with men being less tolerant of constant care.

In our study, nurses maintained that througout the nursing period relatives/caregivers tried to be self-sufficient, to manage on their own and not always willing to accept help. Relatives/caregivers were trained to provide basic and some medical care procedures. Relatives/caregivers were not identified as members of the nursing team; they were trained to be independent providers of home care services. Nurses perceived their work only as assistants to informal caregivers.

Our study also indicates that as a consequence of nursing, changes in lifestyle of informal caregivers becomes a heavy burden as there is no time left for leisure, participation in social events, the quality of communication with friends is poor, the ability to realise their potential is lost. Everyday fatigue leads to health problems. Therefore, the participants in our study perceived that informal caregivers lacked both formal and informal support, inadequate respite services, diminished reimbursement for care aids, and insufficient state provided care allowance.

\section{Conclusions}

This study result shows that in organizing home care for the elderly are lack of cross-sectoral cooperation and teamwork between informal caregivers and community nurses. Therefore, informal caregivers must accept a new role in life as a provider of care, advocating, and supporter roles. Furthermore, as a result of daily fatigue, the informal caregivers' quality of life is deteriorating and their social exclusion is increasing.

\section{References}

1. de Meijer C, Wouterse B, Polder J, Koopmanschap M. The effect of population aging on health expenditure growth: a critical review. European Journal of Ageing 2013;10(4):353-361. https://doi.org/10.1007/s10433-013-0280-x

2. Gibbons SW, Ross A, Bevans M. Liminality as a conceptual frame for understanding the family caregiving rite of passage: An integrative review. Res Nurs Health 2014;37(5):423-436. https://doi.org/10.1002/nur.21622

3. Lindahl B, Lidén E, Lindblad BM. A meta-synthesis describing the relationships between patients, informal caregivers and health professionals in home-care settings. Journal of Clinical Nursing 2011;20(3-4):454-463. https://doi.org/10.1111/j.1365-2702.2009.03008.x

4. Hengelaar AH, van Hartingsveldt M, Wittenberg Y, van EttenJamaludin F, Kwekkeboom R, Satink T. Exploring the collaboration between formal and informal care from the professional perspective-A thematic synthesis. Health Social Care in the Community 2018;26(4):474-485.

https://doi.org/10.1111/hsc.12503

5. Cagle JG, Munn JC. Long-distance caregiving: a systematic review of the literature. Journal of Gerontological Social Work 2012;55(8):682-707. https://doi.org/10.1080/01634372.2012.703763

6. Penrod J, Hupcey JE, Baney BL, Loeb SJ. End-of-life caregiving trajectories. Clinical Nursing Research 2011;20(1):7-24. https://doi.org/10.1177/1054773810384852

7. Freedman VA, Spillman BC. Disability and care needs among older Americans. The Milbank Quarterly 2014;92(3):509-541. https://doi.org/10.1111/1468-0009.12076

8. Wheatley VJ, Baker JI. "Please, I want to go home": ethical issues raised when considering choice of place of care in palliative care. Postgraduate Medical Journal 2007;83(984):643-648. https://doi.org/10.1136/pgmj.2007.058487

9. Nilsen P, Wallerstedt B, Behm L, Ahlström G. Towards evidencebased palliative care in nursing homes in Sweden: a qualitative study informed by the organizational readiness to change theory. Implementation Science 2018;13(1): 1 . https://doi.org/10.1186/s13012-017-0699-0

10. Plöthner M, Schmidt K, de Jong J, Zeidler L, Damm K. Needs and preferences of informal caregivers regarding outpatient care for the elderly: a systematic literature review. BMC Geriatrics 2019;19:82. https://doi.org/10.1186/s12877-019-1068-4

11. Whitlatch C. Informal caregivers: Communication and decision making. Journal of Social Work Education 2008;44(sup3):8995.

https://doi.org/10.5175/JSWE.2008.773247717

12. Miller A D, Mishra SR, Kendall L, Haldar S, Pollack AH, Pratt W.). Partners in care: design considerations for caregivers and patients during a hospital stay. In Proceedings of the 19th ACM Conference on Computer-Supported Cooperative Work Social Computing 2016:756-769. https://doi.org/10.1145/2818048.2819983

13. Salin S, Kaunonen M, Åstedt-Kurki P. Nurses' Perceptions of Their Relationships with Informal Carers in Institutional Respite Care for Older People. Nursing Research and Practice 2013;967084:1-9. https://doi.org/10.1155/2013/967084

14. Lietuvos sveikatos 2014-2025 metų strategija (The Lithuanian health strategy 2014-2025). TAR, 2014 (9403). 
15. Health at a Glance: Europe 2010. OECD 2010. https://ec.europa. $\mathrm{eu} /$ health/sites/health/files/state/docs/health_glance_en.pdf.

16. Health Statistic. http://hi.lt/html/en/health_statistic.htm.

17. Akgun-Citak E, Attepe-Ozden S, Vaskelyte A, van BruchemVisser RL, Pompili S, Kav S, Baskici C. Challenges and needs of informal caregivers in elderly care: Qualitative research in four European countries, the TRACE project. Archives of Gerontology and Geriatrics 2020;87:103971.

https://doi.org/10.1016/j.archger.2019.103971

18. Pietkiewicz I, Smith JA. A practical guide to using interpretative phenomenological analysis in qualitative research psychology. Psychological Journal 2014;20(1):7-14. https://doi.org/10.14691/CPPJ.20.1.7

19. Boeckxstaens P, De Graaf P. Primary care and care for older persons: position paper of the European Forum for Primary Care. Quality in Primary Care 2011;19(6):369.

20. Dahlberg L, McKee KJ. Living on the edge: Social exclusion and the receipt of informal care in older people. Journal of Aging Research 2016;1-10. https://doi.org/10.1155/2016/6373101

21. Bragstad LK., Kirkevold M, Hofoss D, Foss C. Factors predicting a successful post-discharge outcome for individuals aged 80 years and over. International Journal of Integrated Care 2012;10(12):1-10. https://doi.org/10.5334/ijic.691

22. Toscan J, Mairs K, Hinton S, Stolee P. Info Rehab Research Team. Integrated transitional care: patient, informal caregiver and health care provider perspectives on care transitions for older persons with hip fracture. International Journal of Integrated Care 2012;12(13):1-14.

https://doi.org/10.5334/ijic.797

23. Poland F, Mapes S, Pinnock H, Katona C, Sorensen S, Fox C, Maidment ID. Perspectives of carers on medication management in dementia: lessons from collaboratively developing a research proposal. BMC research notes 2014;7(1):463. https://doi.org/10.1186/1756-0500-7-463

24. Dossa A, Bokhour B, Hoenig H. Care transitions from the hospital to home for patients with mobility impairments: patient and family caregiver experiences. Rehabilitation Nursing 2012;37(6):277-285. https://doi.org/10.1002/rnj.047

25. Hansen T, Slagsvold B, Ingebretsen R. The strains and gains of caregiving: an examination of the effects of providing personal care to a parent on a range of indicators of psychological well-being. Social indicators research 2013;114(2):323-343. https://doi.org/10.1007/s11205-012-0148-z

\section{NEFORMALIŲJŲ GLOBE்JU巳 VAIDMUO BENDRUOMENĖS SLAUGYTOJŲ POŽIŪRIU: KOKYBINĖ PRSPEKTYVA}

A. Blaževičienė, A. Vaškelytė, A. Kunčienė

Raktažodžiai: neformalieji globejjai, bendruomenès slaugytojai, namų slauga, kokybinis tyrimas.

\section{Santrauka}

Visuomenès demografinio senèjimo pokyčiai, ilgèjanti vidutiné gyvenimo trukmé didina sveikatos priežiūros ir socialinių paslaugų, orientuotų į vyresnio amžiaus neiggaliujų sveikatos problemų sprendimą, poreikị. Lietuvoje, remiantis Europos Sajungos valstybių nariu patirtimi, siekiama, kad vyresnio amžiaus asmenys kuo ilgiau gyventų savo namuose. Namų slaugos paslaugos apibréžiamos kaip vienos iš prioritetinių Nacionalinès sveikatos strategijos krypčių [14].

Tyrimo tikslas - atskleisti neformaliųų globejjų vaidmenį slaugant namuose savo artimuosius, bendruomenès slaugytojų požiūriu.

Slaugytojai, viename iš Lietuvos regionų teikiantys slaugos paslaugas namuose specialiuosius nuolatinès slaugos poreikius turintiems pacientams, buvo kviečiami dalyvauti sutelktų grupių interviu. Tyrime dalyvavo 31 informantas. Atliekant pusiau struktūruotą interviu, tyrimo dalyviai buvo suskirstyti ị penkias sutelktas grupes. Interviu duomenys buvo analizuojami taikant aprašomosios fenomenologijos metodą.

Atliktas tyrimas atskleidè vieno Lietuvos rajono slaugytojų, teikiančių slaugos paslaugas namuose, bendradarbiavimo patirtị su neformaliaisiais globejjais, slaugančiais šeimos narius namuose. Buvo išskirti trys skirtingi neformaliujų globejų - slaugytojų santykių raidos etapai: 1) slaugos namuose organizavimas šeimos sistemos kontekste, įskaitant naujų vaidmenų sukūrimą šeimos nariams, mezgant bendradarbiavimo santykius su slaugytojais bei artima tarpusavio priklausomybè su slaugomuoju; 2) neformalujų globejjų namų slaugos teikimo galimybių ir iššūkių valdymo fazė, kurios metu neformalieji globejjai įsitraukia ir pasirengia namų slaugai, kad būtų užtikrinamas slaugos nenutrūkstamumas visą parą, formalios ir neformalios pagalbos bei atokvépio paslaugų poreikis; 3) namų slaugos poveikis neformaliuju globejjų gyvenimo kokybei ir sveikatai, susijęs su socialine ir ekonomine slaugymo našta, fizinèmis ir emocinèmis sveikatos problemomis bei dvasinèmis ir etinèmis namų slaugos problemomis.

Šio tyrimo metu atsiskleide tarpsektorinio bendradarbiavimo ir komadinio darbo trūkumas tarp neformaliujų globejų ir bendruomenės slaugytojų, organizuojančių vyresnio amžiaus žmonių slaugą namuose. Bendruomenès slaugytojai neformaliujų globejjų vaidmenį apibrèžè kaip svarbiausią, slaugant artimuosius namuose. Neformalieji globejjai turi susikurti naujus vaidmenis, tokius kaip slaugos ir priežiūros bei paramos teikèjų, advokatų ir kitus. Dèl kasdienès priežiūros namuose ir nuolatinio nuovargio neformaliujų globẻjų gyvenimo kokybẻ blogèja ir jų socialiné atskirtis didejja.

Adresas susirašinèti: alina.vask@gmail.com

Gauta 2021-08-27 